\title{
The value of the jaguar (Panthera onca) according to secondary students
}

\author{
Valores da onça-pintada (Panthera onca) \\ de acordo com alunos secundários
}

\author{
David Figueiredo de Almeida ${ }^{1}$. Lorena dos Santos Maniva $^{2}$ • \\ Carlos Eduardo Costa de Campos ${ }^{3}$
}

\begin{abstract}
This study was conducted in two schools of a city in an inland area of the Brazilian Amazon, with the purpose of describing the values attributed by secondary students to the jaguar (Panthera onca). After the application of the questionnaires and the interviews, it was found that students enrolled in a school located in the center of the town were more able to recognize the ecological value of this animal, while those who studied in the school in the rural area tended to describe the jaguar as a dangerous and frightening animal. However, in both cases, most students support the protection of the jaguar. The diversity of opinions provides a platform for educational measures aimed to protect the jaguar and solve the problems in areas where there are conflicts between humans and this species.
\end{abstract}

Keywords: Environmental education. Amazon. Kellert's Typology. Human Ecology. Environmental Ethics.

Resumo: Este estudo se desenvolveu em duas escolas de um município localizado no interior da Amazônia brasileira, com o objetivo de descrever os valores atribuídos, por alunos de Ensino Médio, à onça-pintada (Panthera onca). Após a aplicação de questionários e realização de entrevistas, observou-se que os alunos oriundos da escola localizada na sede do município reconheceram mais o valor ecológico deste animal, enquanto os alunos da escola localizada na zona rural tenderam a descrevê-lo, sobretudo, como um animal perigoso e amedrontador. Em ambos os casos, porém, a maioria dos alunos apoia a proteção da onça-pintada. A diversidade de olhares representa uma plataforma para medidas educativas que visem à proteção da onça-pintada e a resolução de problemas em zonas onde há conflitos entre seres humanos e esta espécie.

Palavras-chave: Educação ambiental. Amazônia. Tipologia de Kellert. Ecologia humana. Ética ambiental.

\footnotetext{
${ }^{1}$ Programa de Pós-Graduação em Biodiversidade Tropical, Universidade Federal do Amapá, Rodovia Juscelino Kubitscheck, km 01, S/N, Zerão, Macapá, AP, CEP 68900-280. E-mail: <davidfdealmeida@outlook.com>.

${ }^{2}$ Centro Nacional de Primatas, Ananindeua, PA, Brasil.

${ }^{3}$ Departamento de Ciências Biológicas e da Saúde, Universidade Federal do Amapá, Macapá, AP, Brasil.
} 


\section{Introduction}

At times of environmental crisis, the future of non-human animal species depends strongly on the way they are valued by humans. Many animals pose risks to safety, health and human property, leading to conflicts with people (SILLERO-ZUBIRI; SUKUMAR; TREVES, 2007). On the other hand, the animals provide several benefits such as food, medicine, transport, or recreation. Also, the animals are sometimes valued for their ecological importance, regardless of human interests. These different popular visions of the animals may or may not lead to new biodiversity losses, which explains the several studies conducted on human valuing of animals.

In this context, Kellert (1996) presented a typology of values after years of studies conducted in communities of several countries. The typology is formed by nine dimensions of values: utilitaristic (primary interest in the exploration of animals, subordinated to the material interests of human beings), humanistic (there is strong affection for animals, mainly pets), domionistic (interest in the mastery and control over animals, as in activities of sporting hunt and training), negativistic (fear or aversion for animals), aesthetic (primary interest associated to the interest in contemplating beautiful natural scenery, composed of animals), symbolic (animals as symbols of language, thought and communication), ecologistic (primary interest in the ecosystems and interdependence between species), moralistic (opposition against mistreatments and cruelties, worrying with the ethics that say respect to the well-being of animals), and naturalistic (primary interest on the direct experience with wild animals).

Several authors have been studying the popular values associated with the different forms of animals, according to Kellert's classification (1996), and have generally detected differences regarding these values expressed by people of different genders, ages, geographical zones and other variables. Bjerke and Kaltenborn (1999), for example, used Kellert's typology (1996) to study the values attributed to wolves (Canis lupus) by farmers, environmental managers and biologists, in Norway. In the referred study, it was found that although the farmers endorsed some ecologistic values of the wolves, the predation of wolves on sheep flocks usually led to the prioritization of negativistic values. With respect to managers and biologists, there is greater valuing of the ecologistic, moralistic and naturalistic dimensions, which could condition favorable behaviors regarding the preservation of wolves. Other authors have been studying the values of different species according to Kellert's typology (BJERKE; ODEGARDSTUEN; KALTENBORN, 1998; CERÍACO, 2010; FROST, 2000; HUNTER; BREHM, 2004; KÖHLER, 2005; PÁRAMO; GALVIS, 2010; SANTOS; MACHADO, 2006).

The present article is the first scientific study on the valuing of the jaguar (Panthera onca) according to Kellert's typology (1996). The jaguar is the biggest feline of America. One of its main characteristics is its yellow hair with circular black stains that contain smaller stains, although melanic forms are common, which are considered different species by traditional societies (SEYMOUR, 1989). Now, the species is in the "Near Threatened" category according to the classification of the International Union for the Conservation of the Nature and Natural Resources (IUCN), illustrating the importance of studies on the interaction between humans and this animal species. Understanding that Education is one of the most powerful tools for the conservation of biodiversity (PRIMACK; RODRIGUES, 2001), this study was performed in two high schools around a national park of the Brazilian Amazon with the objective of knowing the values more commonly attributed by students to the jaguar. Such studies can be 
useful in the preparation of school curricula and also to assist strategies for the management of protected areas, contributing to a better understanding of the relationships between humans and the wildlife.

\section{Methodology}

The interviewees reside in the municipal district of Serra do Navio, located within the State of Amapá, in the Brazilian Amazon. Serra do Navio is the entrance gate to Tumucumaque Mountains National Park (TMNP), the largest protected area of the world in tropical forest, with 38.464 square kilometers. Biologists have already identified at least 207 species of fish, 70 of amphibians, 86 of reptiles, 366 of birds, 162 of mammals, in addition to 643 genres of plants in this park (BERNARD, 2008). One of the animal species found in the area is the jaguar, of particular concern for this study.

Besides the biological wealth, the municipal district of Serra do Navio also has a rich cultural heritage with historical roots. In the 1960's, 334 houses of different models were constructed for the employees of the Industry and Trade of Ore S. A. (ICOMI), leading to the establishment of Vila de Serra do Navio as the head office (MONTEIRO, 2003). At the same time, some villages of small farmers that supplied their products to the head office began to spread around the area. After the end of ICOMI in 1997, the district faced serious problems, including a slumming process (GALLOIS, 2008), environmental degradation, arsenic pollution in groundwater, and iron uptake in fish (MONTEIRO, 2003). In addition to the head office, the municipal district contains approximately 15 rural communities, where approximately 5 to 600 families live (GALLOIS, 2008) and get most of their livelihoods from farming, cattle breeding, trade, extractivism and public service (SILVA, J. S., 2007).

Schools of the two largest communities of the municipal district were included in this study, since they were the only local institutions of secondary education available at the time of the research: School A, located in the head office of the municipal district, Vila de Serra do Navio; School B, in Colônia de Água Branca. School B is $5 \mathrm{~km}$ away from the head office of Serra do Navio, being one of the closest schools to the TMNP, approximately $50 \mathrm{~km}$ from the boundaries of the referred park.

Forty volunteers from School A $(\mathrm{N}=74)$ and 46 from School B $(\mathrm{N}=93)$ participated in this study. The participants and / or their parents/ legal guardians signed a Free and Informed Consent form and received a certificate for their collaboration in the research after administration of the questionnaires and collection of data through interviews. During questionnaire completion, the students expressed their thoughts about the jaguar and their views about the protection of this species. The students' answers were classified according to Kellert's typology (1996).

In order to obtain more detailed information on the issues addressed in the questionnaire, the students were interviewed. The data were analyzed in the light of the qualitative approach and complemented by quantitative data. The data often concern individuals or groups of individuals for whom the jaguar has a significance, with the encouragement of different views (NASCIMENTO-SCHULZE; CAMARGO, 2000) showing the universe of motives, meanings, aspirations and beliefs that provide a more in-depth understanding of the relationships, phenomena and processes involved (MINAYO, 2002). 


\section{Results and discussion}

The ecologistic values were more frequent in School A $(47.5 \%)$ than in School B $(26.2 \%)$, while in school B the negativistic values $(34.8 \%)$ were more frequent than in School A $(12.5 \%)$. Aesthetic values stood out in both schools (School A: 22.5\%; School B: 21.8\%). The utilitaristic (School A: not recorded; School B: 2.1\%), humanistic (School A: 2.5\%; School B: not recorded), symbolic (School A: 2.5\%; School B: 2.1\%), moralistic (School A: 10\%; School B: 13\%) and naturalistic (School A: 2.5\%; School B: not recorded) values being not very evident. Domionistic values were not reported. Questioned whether the jaguar should be protected, most students answered "Yes" (School A: 87.5\%; School B: 63\%). In School A, 12.5\% of the students, and in School B, 37\% of them, answered "No". Except for one student, all those who were opposed to the protection of the jaguar prioritized negativistic values.

The data indicate that the jaguar has little importance from the point of view of material exploration, because only in one occasion it was associated to utilitaristic values ("It also serves as food, as well as horses, cattle, sheep, armadillos, pacas and deer"). Unlike the attitude adopted by one of the students, the consumption of jaguar meat is not a very common practice which can be explained by several factors such as the ban on hunting of this species and the fact that it is a large predator, usually at the top of the food chain, as well as other large carnivores. However, other reasons might help to elucidate this small preference. The literature contains testimonies given by people who live along river banks about the unpleasant smell, taste and appearance of the jaguar meat (SILVA, A. L., 2007). Silva described associations between the consumption of this animal and symptoms as headache, swelling of the eyes, and dizziness. The jaguar is only consumed in exceptional circumstances, for example, shortage of other animals that are traditionally hunted (JEROZOLIMSKI; PERES, 2003). In Serra do Navio, species such as tapirs (Tapirus terrestris), peccaries (Tayassu pecari), deer (Mazama sp.), and pacas (Cuniculus paca) (GALLOIS, 2008) are frequently hunted.

Moralistic arguments concerned subsistence hunters and the so-called "gateiros" (people who hunt big cats). These people sometimes kill jaguars in self-defense or for their skins for sale. This illegal trade, with the purpose of selling leather goods from these animals, has been pointed as the main reason for the decline in the population of jaguars in the district of Serra do Navio ("The jaguar is very rare in this region because people kill them to sell"; "Humans kill jaguars to remove their leather"; "they are killing a lot of jaguars"; "This animal should be protected because it is often hunted"; "Many people who fear jaguars also bunt them"). Köhler (2005) considers that there is a negative relationship between the utilitaristic and moralistic values, or else, the primarily utilitaristic valuing can sometimes encourage bad practices against animals that provide material benefits for humans. The opposite happened in the cases that the jaguar was valued from the moralistic point of view, when students expressed their great dissatisfaction with the actions of the "gateiros", for whom the value of the jaguar is supposedly more utilitaristic. It is important to stress that the activities of the "gateiros" were forbidden by Brazil's Wildlife Conservation Act, issued in 1967 (BRASIL, 1967), although the data presented here suggest that some "gateiros" are still active in the TMNP.

The moralistic values are closely associated to the humanistic values (KÖHLER, 2005). The recognition, in other organisms, of human characteristics, can contribute to the formation of values that are against ill treatment of these organisms, which was noticed once when jaguars were considered "true athletes" thanks to their hunting and swimming skills. Other 
studies have shown the prevalence of humanistic values over all the other values (BJERKE; ODEGARDSTUEN; KALTENBORN, 1998; KELLERT, 1996; SANTOS; MACHADO, 2006), mainly for domestic animals. Hunter and Brehm (2004) affirm that European youth are more humanistic than North Americans, because the latter were more afraid of wild animals, which can also be the case of most of the youths of Serra do Navio, who prioritize others values, neither moralistic nor humanistic.

Although the moralistic and humanistic views have correlated favorably to the protection of the jaguar, these can be essentially anthropocentric views to the extent that opposition to mistreatment of certain animals is actually a statement of human rights (PERLO, 2007). According to Perlo, mistreatment practices warn of the possibility that humans can also be affected by them. In general, such abuse is more criticized when the victims are more sensitive to pain, as it is the case of humans. Following this line of thought, mistreatments against some organisms are likely to be ignored, while others, such as pets or companion animals, tend to be more protected. Thus, it seems evident that the moralistic values are not the same for all the species. Humans are certainly considered to be in a different category compared to other species, deserving greater life protection, which would justify the extermination of other species considered threats to human well-being. Therefore, the protectionist attitude regarding the jaguar depends on how much the moralistic and humanistic values are extended to other species, such as humans.

The aesthetic attributes of the jaguar were often the most valued by the students ("it is a beautiful animal"; "it is a cute animal"; "the colors are perfect"; "it is a very pretty feline"; "the jaguar beautifies nature"). This view is similar to the concept of "charismatic faun" (PRIMACK; RODRIGUES, 2001) - animals that possesses the people's admiration. This type of valuing might stimulate the collection of funds for protection of species considered beautiful. This can lead to the protection of whole ecosystems, including the animals considered unattractive. However, when aesthetic values are combined with utilitaristic values, it is very likely that the animals are captured for domestication or extraction of their feathers and leathers for example. Colored birds, plants and fish can be cited.

The research instrument used in this study does not indicate the occurrence of the referred practice because nobody mentioned the interest in the jaguar's leather. Nevertheless, this issue needs further clarification. For Schopenhauer (2001), there is an association between contemplation of "beauty" and the "happiness." It is necessary to have a better understanding of what people are capable of doing with the jaguar if its beauty is regarded as a means to achieve a specific end (in this case, more happiness).

Sometimes aesthetic values were intertwined with other values, such as symbolic ("It is a very beautiful animal, one of the symbols of Brazil") and negativistic ("although it is an aggressive animal it is a pretty animal too"; "I don't matter with the jaguar, but I should recognize that it is pretty") values. Particularly in the second case, there were protectionist attitudes towards the jaguar in spite of its dangerousness. There are examples in the literature of how the mix of negativistic values with other values can benefit species that arouse negative feelings in some human communities. In the Himalaya, the snow leopard (Uncia uncia) is regarded as a sinner, born to kill other animals. Killing a leopard, according to this belief means transferring to the hunter all the sins of the slaughtered animal (HUSSAIN, 2002). In this case, the moralistic and symbolic values in opposition to negativistic values prevent a greater killing of leopards by the population. 
In the present study, the negativistic values were always related to an anti-protectionist attitude which is consistent with other studies, such as those of Bjerke and Kaltenborn (1999) and Ceríaco (2010). This was more frequent in School B, because most of the students lived in riverine communities where they would be more likely to have contact with jaguars. For Røskaf et al. (2007), those people tend to have negativistic values of big carnivores because they are aware of the consequences of the proximity of these animals to their houses; that is, the fear of the carnivore and concern with the safety of their family members contribute to these values. This relationship is also confirmed by Kleiven, Bjerke and Kaltenborn (2004), who noticed that people who live far from large carnivores and are less susceptible to be attacked by them tend to be more tolerant of their presence. The interviewees' fear of the jaguar was expressed many times as follows: "dangerous", "evil", "bad", "people's eater", "chaser of other animals" and "an animal that is not good for the community". One student was quoted as saying that "dangerous wild animals should be kept in the zoo" suggesting that only on this condition the jaguar should be preserved.

Probably, the fear of the jaguar is responsible for the low naturalistic valuing in the study area. Only one student was interested in seeing the jaguar "in action, in its natural place." Besides, there are records of lack of interest in naturalistic approaches with aging, and teenagers would be more interested in domestic animals than wild animals (BJERKE; ODEGARDSTUEN; KALTENBORN, 1998).

Ecologistic values prevailed over other values, usually regarding the importance of keeping the jaguar in its natural habitat, as reported in School A " The jaguar is the largest predator of the Brazilian jungles"; "it is very important for the ecosystem balance"; "As a predator, the jaguar plays an important role in nature"; "it is part of the biological cycle and predators are necessary to ecological balance"; "Losing the jaguar is like losing an important character of our ecosystems"). The ecologistic valuing of the jaguar led to the valuing of other ecosystem elements, just as when its extinction was related to ecological unbalances. In fact, it is known that jaguars are opportunistic hunters and promote the balance of their prey population. These preys are predators and/or dispersers of plants, which, in turn, sustain populations of pollinators such as birds and insects. So, the jaguar certainly contributes to the local biological communities (TERBORGH, 1988).

The students' concern with ecologistic values of the jaguar is probably encouraged by the school, particularly in the discipline of biology that includes among its main themes the interaction between different species (BRASIL, 2006). When students come across this theme, they learn concepts like "food chains" and "environmental unbalances" so that the teaching of biology becomes an important tool for the protection of this natural diversity. The prevalence of ecologistic values was also reported in the study of Páramo and Galvis (2010) where ecologistic values followed academic patterns except in the case of youngsters from minority and indigenous communities. For these authors, the prevalence of ecologistic values in the educational system probably explains the low frequency of other values, for example moralist and symbolic values.

\section{Implications for science education}

The jaguar is one of many species that have been victims of habitat destruction and poaching. The benefits of this species to Amazon ecosystems and its presence in local culture 
are probably unique. Unquestionably, it is necessary to take measures aimed at raising awareness about the need to preserve the populations of jaguars. In this scenario, it is important to know the values attributed to the jaguar, because they might justify people's views on the protection of this species. These studies have several implications for science education, making it an increasingly powerful tool for environmental protection.

Intercultural educational processes are one of the implications of environmental valuation studies for science education. The dialogue between scientific culture and the other cultures is important, especially when it comes to environmental protection. For National Curriculum Parameters (BRASIL, 2006), teaching will make more sense if it takes into consideration students' cultural backgrounds. Also, the understanding of the processes will be more effective. Thus, if teachers consider for example the values attributed to jaguars, learning might be more significant and sustainable.

One way to consider how the local culture values the jaguar is by encouraging students to conduct interviews with members of the local community (BRASIL, 2006), by formulating problem situations, such as the jaguar meat in the diet, leather trade, the fear of the people, tales of jaguars in the folklore, their role in nature, etc. Investigative learning methods stimulate the students to face challenges related to their daily lives, developing critical thinking and dialogue and consensus building in conflict situations (ANTUNES, 2007).

Broek (2010) illustrated the importance of cultural backgrounds for science education. Using the so-called "Landscape Model", the author claimed that concepts present in background knowledge are activated through reading, and subsequently connections are established between concepts, forming a landscape, which was demonstrated by computational simulations. While reading a narrative text about a knight, a princess, and a dragon, the author hypothesized the activation of various concepts such as "horse", "forest", "love", "sword", etc. Thus, scientific texts can be designed so as to activate the desired concepts and replace other concepts. In the case of the jaguar, the texts could be used to activate pro-environmental concepts and disable or correct undesirable concepts such as the idea that "dangerous wild animals should be kept in the zoo".

Taking into account all these values also has implications on the role of science education in the ethical training of students. Campbell (2007) believes that there is a difference between science and ethics. According to this author, stating that reduction of environmental protection will harm rare species is science. Deciding whether or not rare species should be protected is ethics. While knowledge about the benefits of stem cell research would have a scientific nature, the values attributed to the embryos would have an ethical nature. Therefore, purely scientific educational processes, without regard to ethics, would be inefficient for the protection of jaguars and other endangered animals. Copland (2003) disagrees with the assertion that science and ethics are separate things, explaining that scientists' familiarity with certain problems always allows them to make judgments supported by scientific facts. So, science is also entitled to affirm whether or not the jaguar should be protected, which does not exclude the right of other spheres of knowledge, such as traditional ecological knowledge and of making their own judgments. The healthy confrontation between different sources of ethical judgment provides students with better conditions to make their own ethical judgments.

In this topic, we demonstrate how different views on the jaguar contribute to the enrichment of scientific education, making it more meaningful to students, andhelps to establish values compatible with the protection of the jaguar and local human communities. 
Almeida, D. F.; Maniva, L. S.; Campos, C. E. C.

\section{Conclusion}

The data analyzed in this study indicate the existence of peculiarities in the valuing of the jaguar by the student populations studied. We evidenced how different views on the jaguar contribute to the enrichment of scientific education, making it more meaningful to high school students. In conflict zones between humans and jaguars, the mere understanding of the ecological importance may not be sufficient to guarantee the protection of this big cat.

\section{Acknowledgements}

We wish to thank Chico Mendes Institute for Conservation of Biodiversity (ICMBio), for logistical support in Serra do Navio, and Dr. Dominique Tilkin Gallois (University of São Paulo, USP), for the suggestions. We also thank the students of the visited schools for their participation in the research.

\section{References}

ANTUNES, C. Professores e professauros. Petrópolis: Vozes, 2007.

BERNARD, E. (Ed.). Inventários biológicos rápidos no parque nacional Montanhas do Tumucumaque, Amapá, Brasil. Arlington: Conservation International, 2008. (RAP: bulletin of biologial assessment, 48). Disponível em: <http://www.iepa.ap.gov.br/biblioteca/ artigo2014/inventarios-biologicos-tumucumaque-amapa.pdf>. Acesso em: 03 nov. 2014.

BJERKE, T.; KALTENBORN, B. P. The relationship of ecocentric and anthropocentric motives to attitudes toward large carnivores. Journal of Environmental Psychology, London, v. 19, n. 4, p. 415-421, 1999.

BJERKE, T.; ODEGARDSTUEN, T. S.; KALTENBORN, B. P. Attitudes toward animals among Norwegian adolescents. Anthrozoos, Davis, v. 11, n. 2, p. 79-86, 1998. Disponível em: <http://www.petpartners.org/document.doc?id=30>. Acesso em: 03 nov. 2014.

BRASIL. Lei N 5.197, de 3 de janeiro de 1967. Dispõe sobre a proteção à fauna e dá outras providências. Diário Oficial da União, Brasília, 05 jan. 1967. Disponível em: < http://www. planalto.gov.br/ccivil_03/leis/15197.htm>. Acesso em: 03 nov. 2014.

BRASIL. Ministério da Educação e do Desporto. Orientações curriculares para o ensino médio: ciências da natureza, matemática e suas tecnologias. Brasília, 2006. 
BROEK, P. V. D. Using texts in science education: cognitive processes and knowledge representation. Science, Washington, v. 328, n. 5977, p. 453-456, 2010.

CAMPBELL, D. Need to distinguish science (good or bad) from ethics. Nature, London, v. 446, n. 44, p. 24, 2007.

CERÍACO, L. M. P. Human attitudes towards herpetofauna: how preferences fear and beliefs can influence the conservation of reptiles and amphibians. 2010. 164 f. Dissertação (Mestrado em Biologia da Conservação) - Universidade de Évora, Évora, 2010.

COPLAND, P. Science and ethics must not be separated. Nature, London, v. 425, p. 121, 2003.

FROST, C. J. Comparing attitudes about forests between young adults in NorthCentral Florida and the Peruvian Amazon. 2000. 291 f. Thesis (M. S.) - University of Florida, Gainesville, 2000.

GALLOIS, D. T. Levantamento histórico-cultural do parque nacional montanhas do Tumucumaque. Brasília: MMA, 2008. (Relatório de pesquisa).

HUNTER, L. M.; BREHM, J. M. A qualitative examination of value orientations toward wildlife and biodiversity by rural residents of the intermountain region. Human Ecology Review, Bar Harbor, n. 11, n. 1, p. 13-26, 2004.

HUSSAIN, S. Nature and human nature: conservation, values and snow leopard. In: SNOW LEOPARD SURVIVAL STRATEGY WORKSHOP, 2002. Proceedings... Seattle:

International Snow Leopard Trust, 2002. Disponível em: <http://www.snowleopardnetwork. org/bibliography/Hussain_2002.pdf> Acesso em: 11 jun. 2013.

JEROZOLIMSKI, A.; PERES, C. A. Bringing home the biggest bacon: a cross-site analysis of the structure of hunter-kill profiles in Neotropical forests. Biological Conservation, Amsterdam, n. 111, n. 3, p. 415-425, 2003.

KELLERT, S. R. The value of life: biological diversity and human society. New York: Island Press, 1996.

KLEIVEN, J.; BJERKE, T.; KALTENBORN, B. P. Factors influencing the social acceptability of large carnivore behaviours. Biodiversity \& Conservation, Dordrecht, v. 13, n. 9, p. 1647-1658, 2004.

KÖHLER, K. F. M. Wohlbefinden landwirtschaftlicher Nutztiere:

nutztierwissenschaftliche Erkenntnisse und gesellschaftliche Einstellungen. 2005. 279 f.

Dissertation (zur Erlangung des Doktorgrades) - Institut für Agrarökonomie, Agrar - und

Ernährungswissenschaftlichen Fakultät, Christian-Albrechts-Universität zu Kiel, Kiel, 2005.

Disponível em: <http://macau.uni-kiel.de/receive/dissertation_diss_00001545>. Acesso em: 03 nov. 2014.

MINAYO, M. C. S. Pesquisa social: teoria, método e criatividade. Petrópolis: Vozes, 2002.

MONTEIRO, M. A. A ICOMI no Amapá: meio século de exploração mineral. Novos

Cadernos NAEA, Belém, n. 6, p. 113-168, 2003. 
Almeida, D. F.; Maniva, L. S.; Campos, C. E. C.

NASCIMENTO-SCHULZE, C. M.; CAMARGO, B. V. Psicologia social, representações sociais e métodos. Temas de Psicologia, Ribeirão Preto, v. 8, n. 3, p. 287-299, 2000.

Disponível em: < http://pepsic.bvsalud.org/pdf/tp/v8n3/v8n3a07.pdf>. Acesso em: 03 nov. 2014.

PÁRAMO, P.; GALVIS, C. J. Conceptualizaciones acerca de los animales en niños de la sociedad mayoritaria y de la comunidad indígena Uitoto en Colombia. Folios, Bogotá, n. 32, p. 111-124, 2010. Disponível em: <http://www.scielo.org.co/pdf/folios/n32/n32a07.pdf>. Acesso em: 03 nov. 2014.

PERLO, K. Extrinsic and intrinsic arguments: strategies for promoting animal rights.

Journal for Critical Animal Studies, Syracuse, v. 5, n. 1, p. 1-14, 2007.

PRIMACK, R. B.; RODRIGUES, E. Biologia da conservação. São Paulo: Planta, 2001.

RØSKAF, E. et al. Human attitudes towards large carnivores in Norway. Wildlife Biology, Hornslet, v. 13, n. 2, p. 172-185, 2007.

SANTOS, V. L.; MACHADO, L. M. C. P. Vínculos topo-biofílicos nas interações visitantes e paisagem rural em Itu/SP. In: GERARDI, L. H. O.; CARVALHO, P. F. (Org.). Geografia: ações e reflexões. Rio Claro: UNESP/IGCE: AGETEO, 2006. p. 305-320.

SCHOPENHAUER, A. O mundo como vontade e representação. Rio de Janeiro: Contraponto, 2001.

SEYMOUR, K. L. Panthera onca (Linnaeus, 1758). Mammalian Species, Lawrence, n. 340, p. 1-9, 1989.

SILLERO-ZUBIRI, C.; SUKUMAR, R.; TREVES, A. Living with wildlife: the roots of conflict and the solutions. In: McDONALD, D. W.; SERVICE, K. (Org.). Key topics in conservation biology. Oxford: Oxford University Press, 2007. p. 253-270.

SILVA, A. L. Comida de gente: preferências e tabus alimentares entre os ribeirinhos do Médio Rio Negro (Amazonas, Brasil). Revista de Antropologia, São Paulo, v. 50, n. 1, p. 125-179, 2007.

SILVA, J. S. (Org.). Plano de desenvolvimento rural sustentável da Serra do Navio. Macapá: [s.n.], 2007. Mimeografado.

TERBORGH, J. The big things that run the world: a sequel to E. O. Wilson. Conservation Biology, Washington, v. 2, n. 4, p. 402-403, 1988.

Artigo recebido em 11/06/13. Aceito em 09/08/14. 